\title{
Genetic and environmental parameters for milk production, udder health, and fertility traits in Mexican Holstein cows
}

\author{
H. H. Montaldo, ${ }^{1}$ H. Castillo-Juárez,† M. Valencia-Posadas,‡ E. G. Cienfuegos-Rivas,§ and F. J. Ruiz-López\# \\ *Departamento de Genética y Bioestadística, Facultad de Medicina Veterinaria y Zootecnia, Universidad Nacional Autónoma de México, \\ Ciudad Universitaria, 04510, Distrito Federal, México \\ †Departamento de Producción Agrícola y Animal, Universidad Autónoma Metropolitana-Xochimilco, Calzada del Hueso 1100, 04960, \\ Distrito Federal, México \\ ‡División de Ciencias de la Vida, Campus Irapuato-Salamanca, Universidad de Guanajuato, Ex Hacienda El Copal, 36500, Irapuato, \\ Guanajuato, México \\ §Universidad Autónoma de Tamaulipas, 87030, Cd. Victoria, Tamaulipas, México \\ \#Centro Nacional de Investigación en Fisiología y Mejoramiento Animal, Instituto Nacional de Investigaciones Forestales, Agrícolas y Pecuarias: \\ Secretaría de Agricultura, Ganadería, Desarrollo Rural, Pesca y Alimentación, 76280, Ajuchitlán, Querétaro, México
}

\section{ABSTRACT}

Genetic and phenotypic parameters for Mexican Holstein cows were estimated for first- to third-parity cows with records from 1998 to 2003 ( $\mathrm{n}=2,971-15,927)$ for 305-d mature equivalent milk production (MEM), fat production (MEF), and protein production (MEP), somatic cell score (SCS), subsequent calving interval (CAI), and age at first calving (AFC). Genetic parameters were obtained by average information matrixREML methodology using 6-trait (first-parity data) and 5-trait (second- and third-parity data) animal models. Heritability estimates for production traits were between $0.17 \pm 0.02$ and $0.23 \pm 0.02$ for first- and second-parity cows and between $0.12 \pm 0.03$ and 0.13 \pm 0.03 for third-parity cows. Heritability estimates for SCS were similar for all parities $(0.10 \pm 0.02$ to 0.11 $\pm 0.03)$. For CAI, estimates of heritability were $0.01 \pm$ 0.05 for third-parity cows and $0.02 \pm 0.02$ for secondparity cows. The heritability for AFC was moderate $(0.28 \pm 0.03)$. No unfavorable estimates of correlations were found among MEM, MEF, MEP, CAI, and SCS. Estimates of environmental and phenotypic correlations were large and positive among production traits; favorable between SCS and CAI; slightly favorable between MEM, MEF, and MEP and SCS, between AFC and SCS, and between SCS and CAI; and small but unfavorable between production traits and CAI. Estimates of genetic variation and heritability indicate that selection would result in genetic improvement of production traits, AFC, and SCS. Estimates of both heritability and genetic variation for CAI were small, which indicates that genetic improvement would be difficult.

Received January 26, 2009.

Accepted January 18, 2010.

${ }^{1}$ Corresponding author: montaldo@servidor.unam.mx
Key words: genetic parameter, milk production trait, somatic cell score, fertility

\section{INTRODUCTION}

Estimates of genetic parameters for traits of economic importance in dairy cattle are necessary for implementing efficient breeding programs. Accurate heritability and correlation estimates are required to predict expected selection response and to obtain predicted breeding values using mixed model (BLUP) procedures. Traits related to milk, fat, and protein production, conformation, length of productive life, reproduction, workability, and health are included in breeding programs of dairy cattle in many countries (Mark, 2004; VanRaden, 2004) to maximize improvement of a breeding goal involving traits related to income and costs (e.g., Dekkers and Gibson, 1998).

In Mexico, total milk production increased from 7.8 million tonnes in 1997 to 10.3 million tonnes in 2007. The dairy cow population was approximately 2.2 million in 2005 (SIAP-SAGARPA, 2009). In 2007, approximately $50 \%$ of milk was produced by specialized dairy herds comprising approximately 0.85 million cows. These herds are mainly Holstein or Holstein-type managed in conventional production systems (Montaldo et al., 2009) mostly in 2 climatic regions: temperate areas in the high valleys of central Mexico and arid regions of northern Mexico (SIAP-SAGARPA, 2009).

In Mexico, $54 \%$ of milk is processed as fluid pasteurized milk, $23 \%$ is processed as evaporated and condensed milk, and the remaining $23 \%$ is used to produce other products such as cheese and yogurt (FAO-SAGARPA, 2002). These statistics indicate that protein and fat production are of economic importance for Mexico. As with other Holstein populations, the economic objective should consider these 2 milk components as well as functional traits to increase net profit (e.g., VanRaden, 
2004; Valencia et al., 2008). Economic weights for traits in the breeding objective to increase net profit for local conditions still need to be developed (e.g., Dekkers and Gibson, 1998; Valencia et al., 2008).

The development of the Holstein breed in Mexico in the past $30 \mathrm{yr}$ has been mainly based on imports of live animals, semen, and embryos from the United States (US), Canada, and, more recently, from Europe and Oceania (Powell and Wiggans, 1991; Valencia et al., 1999). The number of registered cows in the official milk recording system of the Holstein Association (Querétaro, México) used for genetic evaluation purposes was approximately 42,000 in 2008 . The number of cows officially recorded is approximately only $4.9 \%$ of cows in specialized herds. Genetic evaluation for milk production of Mexican Holsteins began in 1974 by the USDA (Powell and Wiggans, 1991) and has been carried out since 1998 by the Mexican Holstein Association (Valencia et al., 1999). Genetic evaluations are currently done once a year for milk, fat, and protein yields as well as for fat and protein percentages using single trait repeatability models.

Organizing a progeny testing program for young sires has been challenging. Development of a national system for genetic improvement of this population is needed. Estimation of genetic parameters for traits of economic importance for this population is a priority.

Previous estimates of genetic parameters for the Mexican Holstein population involved milk yield (Cienfuegos-Rivas et al., 1999; Valencia et al., 2004a,b, 2008), herd life (Valencia et al., 2004b), and type traits (Valencia et al., 2008). However, previous estimates are not available from multiple trait analyses of production traits, SCS, and calving interval for the Mexican Holstein population with an animal model.

The objective of this study was to estimate (co)variances, heritabilities, and genetic, environmental, and phenotypic correlations for 305-d mature equivalent milk (MEM), fat (MEF), and protein (MEP) yields, SCS, calving interval (CAI), and age at first calving (AFC) in Holstein cattle from Mexico.

\section{MATERIALS AND METHODS}

\section{Data and Edits}

Data from cows calving between 1998 and 2003 were obtained from the Mexican Holstein Association. Firstto third-parity records were included in the analysis. Traits analyzed were 305-d MEM, MEF, and MEP and subsequent CAI and AFC. Somatic cell score in this study was $\log _{2}(\mathrm{SCC} / 100,000)+3$ (Neuenschwander et al., 2005), where SCC was the unadjusted test-day SCC averaged for all test-days. Records for 305-d com- plete lactations were obtained using the test-interval method. Incomplete lactations with 100 to 304 DIM were projected to 305-d using methods based on functions of last sample productions (Wiggans and Van Vleck, 1979).

Records of nonregistered animals and those with unknown sires or dams were excluded from the analysis. Permissible values in the recording system were less than 21,000 kg for MEM and between 0 and 9 for SCS. To exclude possibly erroneous records, lactation records less than or greater than 4 SD from the mean for MEM, MEF, or MEP were not used. Based on an analysis of the distributions of milk production and content traits, records of less than $58.5 \mathrm{~kg}$ of MEF, $50.0 \mathrm{~kg}$ of MEP, $2.0 \%$ of fat, or $2.5 \%$ of protein were not used, nor were those with more than $5 \%$ of fat and $4 \%$ of protein. Records greater than $4 \mathrm{SD}$ from the mean for AFC $(1,308 \mathrm{~d})$ and CAI $(1,146 \mathrm{~d})$ or less than the assumed biological limit for AFC (549 d) or CAI (293 d) were excluded.

The final data set included records from a total of 13,201 cows from 69 herds. Number of records for traits other than milk and those from second and third parities were lower (Table 1 ). The pedigree file included 40,489 animals, of which 2,885 were sires and 19,542 were dams, plus 18,062 cows without progeny. Animals in the pedigree file were born between 1992 and 2001.

\section{Model and Analysis}

Models included fixed effects of herd-year-season of calving with 2 seasons (January to June and July to December) and number of times milked per day with 2 levels $(2 \times$ or $3 \times)$. Almost all lactations were milked in either 2 or 3 times/d during the whole $305-d$ period. For first-parity data, AFC and AFC squared were used as covariates for all yield traits, SCS, and CAI. In the case of AFC, the effect of herd-year-season of birth was used instead of the herd-year-season of calving. The models included random animal genetic effects. ASReml software (Gilmour et al., 2002) was used to estimate (co) variances, heritabilities, and genetic, environmental, and phenotypic correlations and their standard errors. Phenotypic variances were calculated as the animal plus residual components of variance.

In matrix notation, the multitrait models were

$$
\mathbf{y}=\mathbf{X b}+\mathbf{Z u}+\mathbf{e}
$$

where $\mathbf{y}$ is the vector of records for MEM, MEF, MEP, SCS, CAI, and AFC; $\mathbf{b}$ is the vector of fixed effects containing the effects of herd-year-season of calving and linear and quadratic effects of AFC for milk yield 
Table 1. Descriptive statistics for milk production, udder health, and fertility traits for registered Mexican Holsteins for the first 3 parities

\begin{tabular}{|c|c|c|c|c|c|c|c|}
\hline Parity & Trait $^{1}$ & $\mathrm{n}$ & Mean & Minimum & Maximum & $\mathrm{SD}$ & $\mathrm{CV}(\%)$ \\
\hline \multirow{4}{*}{ First } & MEF (kg) & 13,201 & 387 & 79 & 704 & 88 & 22.8 \\
\hline & MEP (kg) & 13,201 & 350 & 89 & 562 & 71 & 20.2 \\
\hline & $\mathrm{CAI}(\mathrm{d})$ & 6,524 & 419 & 293 & 1,146 & 101 & 24.1 \\
\hline & $\operatorname{AFC}(\mathrm{d})$ & 13,201 & 798 & 556 & 1,308 & 119 & 14.9 \\
\hline \multirow[t]{2}{*}{ Second } & MEM (kg) & 10,761 & 11,001 & 3,030 & 17,000 & 2,802 & 25.5 \\
\hline & $\mathrm{CAI}(\mathrm{d})$ & 4,501 & 416 & 293 & 729 & 83 & 20.1 \\
\hline \multirow[t]{5}{*}{ Third } & MEM (kg) & 6,800 & 10,307 & 3,040 & 16,920 & 2,715 & 26.3 \\
\hline & MEF (kg) & 6,800 & 358 & 91 & 705 & 100 & 27.8 \\
\hline & MEP (kg) & 6,800 & 319 & 84 & 544 & 80 & 25.1 \\
\hline & SCS $\left(\log _{2}\right.$ SCC $)$ & 6,800 & 3.49 & 0 & 9 & 1.74 & 49.8 \\
\hline & CAI (d) & 2,576 & 421 & 294 & 730 & 84 & 20.0 \\
\hline
\end{tabular}

${ }^{1} \mathrm{MEM}=$ mature equivalent milk production; $\mathrm{MEF}=$ mature equivalent fat production; $\mathrm{MEP}=$ mature equivalent protein production; $\mathrm{CAI}=$ calving interval; AFC = age at first calving.

traits, SCS and CAI, and herd-year-season of birth for age at first calving; $\mathbf{u}$ is the vector of random animal effects, including animals without records; $\mathbf{e}$ is the vector of random residual effects; and $\mathbf{X}$ and $\mathbf{Z}$ are incidence matrices assigning observations to fixed and random animal effects, respectively.

Expectations $(\mathbf{E})$ and covariance matrices $(\mathbf{V})$ of random vectors are described in the following equations:

$$
\begin{gathered}
\mathbf{E}\left[\begin{array}{l}
\mathrm{u} \\
\mathrm{e}
\end{array}\right]=\left[\begin{array}{l}
0 \\
0
\end{array}\right] \text { and } \\
\mathbf{V}\left[\begin{array}{l}
\mathrm{u} \\
\mathrm{e}
\end{array}\right]=\left[\begin{array}{ll}
\mathbf{G} & 0 \\
0 & \mathbf{R}
\end{array}\right],
\end{gathered}
$$

where $\mathbf{G}=\mathbf{A} \otimes \mathbf{G}_{0}$ (A is the numerator relationship matrix; $\mathbf{G}_{0}$ is the genetic (co)variance matrix; and $\otimes$ is the Kronecker product) and $\mathbf{R}$ is the residual (co)variance matrix. Starting values for elements of (co)variance genetic and environmental matrices were estimates obtained from preliminary single trait model analyses and from assumed correlations.

Estimates of heritability and correlation coefficients were considered significantly different from $0(P<$ 0.01 ) when the parameter estimate was at least 3 times the value of the standard error of the estimate, and $P<0.05$ when the parameter estimate was at least twice the value of the standard error of the estimate. This is an approximate rule that is valid for significance testing of the parameters estimated with large samples such as in this case, by assuming normal distributions of the estimates (Åkesson et al., 2008).

\section{RESULTS AND DISCUSSION}

\section{Phenotypic Means and Variability}

Descriptive statistics for the variables studied are shown in Table 1. Table 2 shows estimates of additive genetic and phenotypic variances as well as the heritabilities for the traits studied. Tables 3, 4, and 5 show estimates of genetic, environmental, and phenotypic correlations. Means for most traits were approximately similar to those for US Holsteins. Compared with US averages for the year 2000, the approximate average differences were $-3.6,-9.8,-0.3$, and $3.2 \%$ for MEM, MEF, MEP, and SCS, respectively (USDA-ARS, 2009), and -0.8 and $1.5 \%$ for $\mathrm{AFC}$ and $\mathrm{CAI}$, respectively (Hare et al., 2006). Average SCS values were 2.67 for US Holstein cows and 2.76 in this present study.

For MEM, MEF, and MEP, the differences between parities suggest a small overadjustment of first-parity records (Table 1). For traits that were not adjusted to a mature equivalent basis, means for SCS increased with parity, but means for CAI were similar (Table 1). The phenotypic CV increased from first to later parities for MEM, MEF, and MEP, but decreased for SCS and CAI (Table 1).

\section{Herd-Year-Season Effects}

Herd-year-season effects accounted for a substantial proportion of total variation in most variables estimated from the difference between unadjusted and phenotypic variances obtained from the model: from 7.6 to $9.7 \%$ for CAI and 23.7 to $35.4 \%$ for MEM, MEF, and MEP. These percentages decreased as the parity increased (Table 2). The proportions for SCS were similar across 
Table 2. Model statistics and heritabilities for milk production, udder health, and fertility traits for registered Mexican Holsteins for the first 3 parities

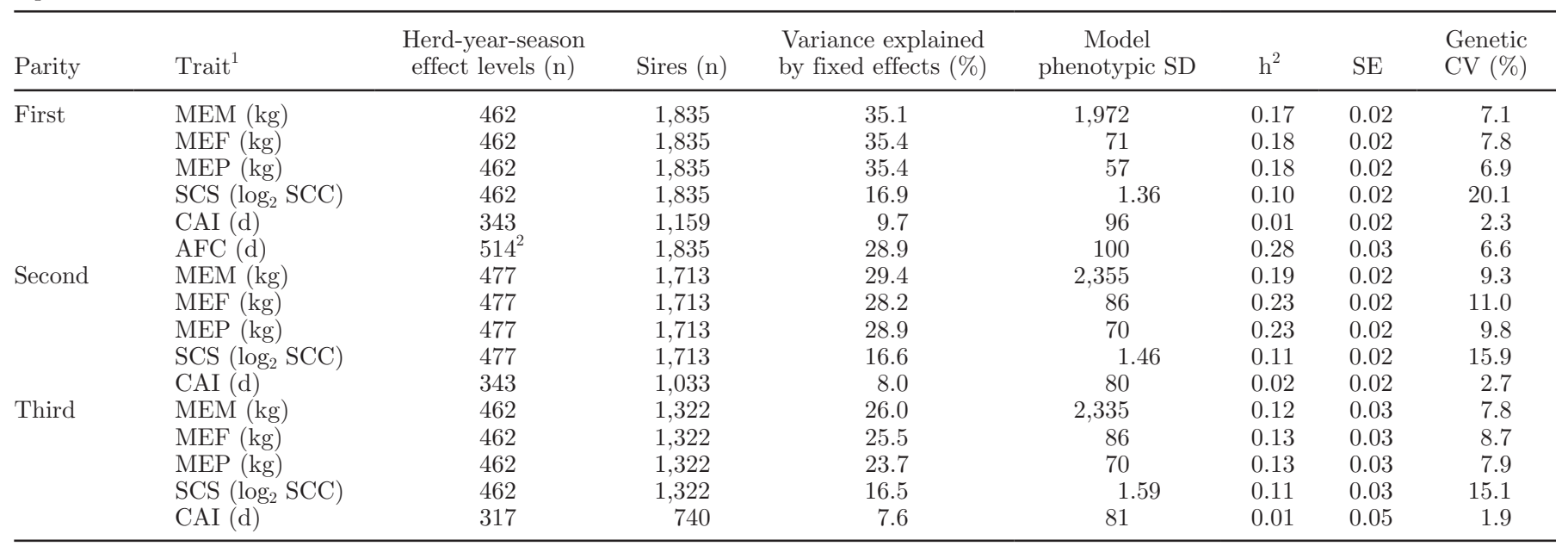

${ }^{1} \mathrm{MEM}=$ mature equivalent milk production; $\mathrm{MEF}=$ mature equivalent fat production; $\mathrm{MEP}=$ mature equivalent protein production; $\mathrm{CAI}=$ calving interval; $\mathrm{AFC}=$ age at first calving.

${ }^{2}$ Herd-year season of birth.

parities (16.5-16.9\%; Table 2). This value for CAI is unexpectedly low. One reason might be that most of the herds contributing records were elite herds with generally good reproductive management.

\section{Heritabilities and Genetic Variation}

Heritability estimates for yield traits were higher for first- and second-parity cows (0.17-0.23) compared with estimates for third-parity cows $(0.12-0.13$; Table 2 ). However, results for third-parity cows are based on smaller sample sizes. Heritability estimates for SCS and
CAI were similar across parities. Values for SCS were between 0.10 and 0.11 , and heritability estimates for CAI were from 0.01 for first- and third-parity cows and 0.02 for second-parity cows.

The coefficients of additive genetic variation (CAV) of a trait give additional information to the heritability or the phenotypic variance, indicating the potential for genetic change, relative to their averages. For MEM and MEP the genetic coefficients of variation were similar within lactation, with values ranging between 7.1 and $9.8 \%$. The CAV for MEF was slightly larger and varied from 7.8 to $11.0 \%$ (Table 2). The CAV for AFC was

Table 3. Genetic, environmental, and phenotypic correlations for primiparous Mexican Holsteins

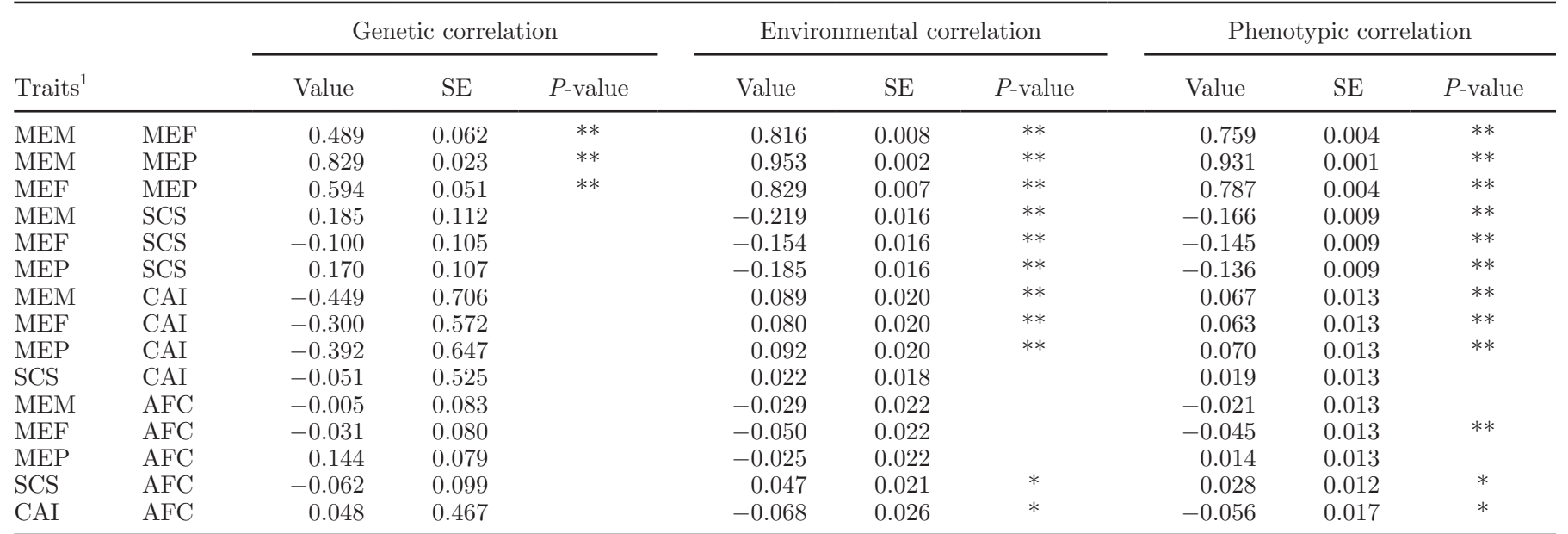

${ }^{1} \mathrm{MEM}=$ mature equivalent milk production; $\mathrm{MEF}=$ mature equivalent fat production; $\mathrm{MEP}=$ mature equivalent protein production; $\mathrm{CAI}=$ calving interval; $\mathrm{AFC}=$ age at first calving.

${ }^{*} P<0.05 ;{ }^{* *} P<0.01$. 
Table 4. Genetic, environmental, and phenotypic correlations for second-calving Mexican Holsteins

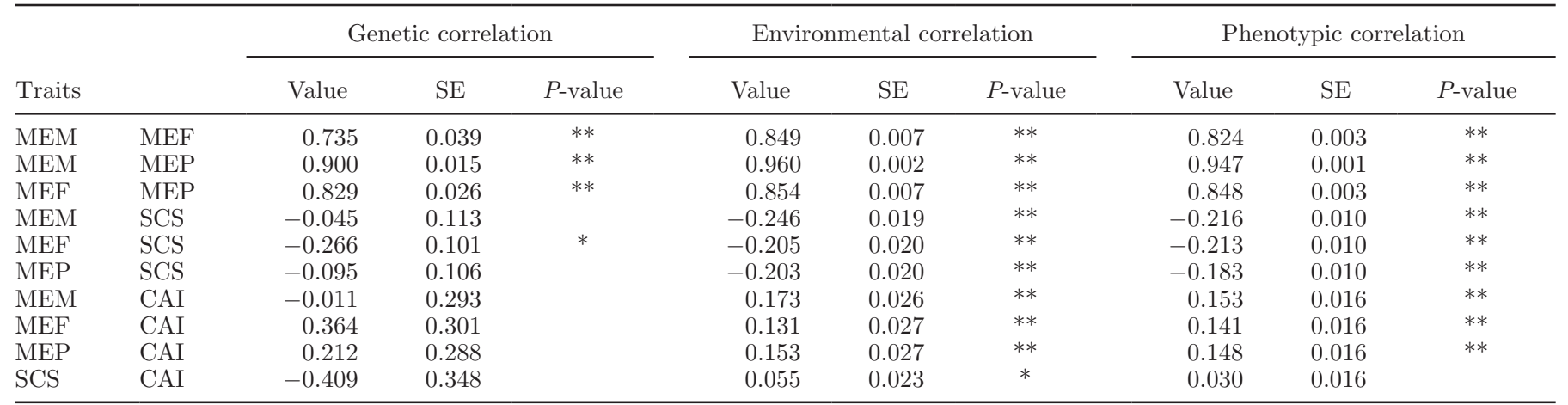

${ }^{1} \mathrm{MEM}=$ mature equivalent milk production; $\mathrm{MEF}=$ mature equivalent fat production; $\mathrm{MEP}=$ mature equivalent protein production; $\mathrm{CAI}=$ calving interval.

${ }^{*} P<0.05 ;{ }^{* *} P<0.01$.

6.6\%. The CAV range for CAI was 1.9 to $2.7 \%$ (Table 2). The larger CAV observed was for SCS, with a value ranging from 15.1 to $20.1 \%$ (Table 2).

Estimates of heritability for MEM were in the lower part of the range reported by most authors for Mexican data (0.18-0.31; Valencia et al., 2004a,b) and elsewhere (0.12- 0.39) (Raffrenato et al., 2003; Weller and Ezra, 2004; Dechow et al., 2007). Estimates of heritability for MEM were greater for first- and second-parity cows (0.17-0.19) than for third-parity cows (0.13). Carlén et al. (2004) reported for MEM larger estimates of heritability and a reduction from 0.34 to 0.23 for first- to third-parity cows. Similarly, Weller and Ezra (2004) reported a reduction in heritability from 0.39 to 0.27 for MEM of first- to third-parity cows.

Estimates of heritability for MEP $(0.13-0.23)$ were within the range of previous estimates (0.09-0.31; e.g., Van Tassell et al., 2000; Hansen et al., 2002; AndersenRanberg et al., 2005), with smaller estimates for thirdparity cows. Weller and Ezra (2004) also reported a reduction in estimates for heritability of protein yield from 0.34 to 0.27 for first- to third-parity cows.

Heritability estimates for MEF were within the range of the published reports of 0.09 to 0.36 (e.g., Abdallah and McDaniel, 2000; Carlén et al., 2004; Ikonen et al., 2004). These estimates were greater for the first 2 parities (0.18 and 0.23 for parities 1 and 2, respectively) than for the third parity (0.13). Smaller heritability estimates for later parities were also reported by Carlén et al. (2004) and Weller and Ezra (2004) for Swedish and Israeli dairy cows, respectively.

Estimates of heritability for SCS were between 0.10 and 0.11 (Table 2). Several authors have reported estimates mostly in the range of 0.09 to 0.12 (e.g., Banos and Shook, 1990; Castillo-Juarez et al., 2000; de Haas et al., 2008) for Israeli Holsteins, although some have reported estimates as large as 0.25 (Weller and Ezra, 2004).

Heritability estimates for CAI were small for all parities (0.01-0.02; Table 2). Relatively small estimates (i.e.,

Table 5. Genetic, environmental, and phenotypic correlations for third-calving Mexican Holsteins

\begin{tabular}{|c|c|c|c|c|c|c|c|c|c|c|}
\hline Traits & & \multicolumn{3}{|c|}{ Genetic correlation } & \multicolumn{3}{|c|}{ Environmental correlation } & \multicolumn{3}{|c|}{ Phenotypic correlation } \\
\hline MEM & MEF & 0.638 & 0.084 & $* *$ & 0.879 & 0.007 & $* *$ & 0.849 & 0.004 & $* *$ \\
\hline MEF & MEP & 0.755 & 0.060 & $* *$ & 0.883 & 0.006 & $* *$ & 0.866 & 0.003 & $* *$ \\
\hline MEM & SCS & -0.078 & 0.168 & & -0.243 & 0.022 & $* *$ & -0.225 & 0.012 & $* *$ \\
\hline MEF & SCS & -0.274 & 0.159 & & -0.221 & 0.023 & $* *$ & -0.227 & 0.012 & $* *$ \\
\hline MEF & CAI & -0.149 & 0.674 & & 0.151 & 0.035 & $* *$ & 0.134 & 0.021 & $* *$ \\
\hline MEP & CAI & -0.166 & 0.690 & & 0.164 & 0.035 & $* *$ & 0.145 & 0.022 & $* *$ \\
\hline SCS & CAI & -0.391 & 0.922 & & 0.074 & 0.034 & $*$ & 0.054 & 0.022 & $*$ \\
\hline
\end{tabular}

${ }^{1} \mathrm{MEM}=$ mature equivalent milk production; $\mathrm{MEF}=$ mature equivalent fat production; $\mathrm{MEP}=$ mature equivalent protein production; $\mathrm{CAI}=$ calving interval.

${ }^{*} P<0.05 ;{ }^{* *} P<0.01$. 
$<0.10)$ are common for many fertility traits in dairy cows. VanRaden et al. (2004), in a review of estimates used for genetic evaluations of fertility traits worldwide, concluded that fertility traits in dairy cattle populations have heritability of 0.04 or less. They reported an estimate of heritability for days open in the US Holstein population as 0.04. Mark (2004) also reviewed the values of the genetic parameters used in several countries for genetic evaluations and found that heritabilities for fertility traits ranged from 0.01 to 0.07 . Estimates from the current study are similar to those reported by Haile-Mariam et al. (2008) in Australia (0.02-0.04) and are slightly less than estimates by González-Recio and Alenda (2005) in Spain (0.04) and by Olori et al. (2002) in the Netherlands (0.04).

The estimate of heritability for AFC was moderate (0.28; Table 2). It was larger than the heritability observed for Canadian Holsteins (0.04) by Moore et al. (1991) or for Brazilian (0.19) and Colombian (0.13) Holsteins by Cerón-Muñoz et al. (2004). The estimate from the current study was similar to that of 0.26 by Shanks et al. (1982) for US Holsteins but was smaller than the estimate by Ojango and Pollott (2001) of 0.38 for Kenyan Holstein cattle and by Ruiz-Sánchez et al. (2007) of 0.47 with US data. Pirlo et al. (2000) have pointed out that estimates of heritability of AFC are in a wide range $(0.05-0.75)$ and that inconsistencies in estimates may be caused by confounding of sire and management effects.

Differences between the estimates of heritability obtained in this study and estimates from other countries are most likely caused by management and climate differences affecting genetic and environmental variances.

Emphasis given to traits in the breeding programs will be dictated by economic and social considerations. The inclusion of traits with small estimates of heritability in progeny testing programs of sires such as CAI and SCS is possible, but to reach a minimum reliability for PTA, more daughter records would be necessary for the evaluation of a sire for an index involving production traits, AFC, SCS, and CAI than for MEM, MEF, $\mathrm{MEP}$, and AFC alone.

\section{Genetic Correlations}

Estimates of genetic correlations among milk production traits were positive. Estimates for MEM with MEP and MEF were 0.83 and 0.49 , respectively, and for MEP and MEF was 0.59 for first-parity data (Table 3 ). These estimates were similar to those reported by Dechow et al. (2007) for a small number of herds in the US $(0.73,0.40$, and 0.55 , respectively) and very close to those reported by Castillo-Juarez et al. (2002) for US Holsteins $(0.83,0.49$, and 0.66). Using data from the
Netherlands, Veerkamp et al. (2001) obtained similar estimates for the genetic correlation between 305-d milk and protein yields (0.84), between 305-d milk and fat yields (0.41), and between 305-d protein and fat yields (0.55). Estimates of genetic correlations among production traits had a similar pattern trend but were slightly greater for later parities (Tables 4 and 5).

Estimates of genetic correlations between production traits and SCS were generally close to zero and not significant, with estimates ranging from -0.06 to 0.19 for first-parity cows (Table 3), from -0.27 to -0.05 for second-parity cows (Table 4 ) and from -0.27 to -0.08 for third-parity cows (Table 5). The only estimate significantly different from zero was favorable $(-0.27)$ between MEF and SCS in second-parity cows (Table 4). These estimates agree with those reported by Pösö and Mäntysaari (1996) for Ayrshire cattle but do not agree with most other estimates of the genetic correlation between milk and SCS, which have been rather moderate and positive (Welper and Freeman, 1992; Castillo-Juarez et al., 2000; Dechow et al., 2007). Other findings show a wide variation of these estimates, from -0.15 (Banos and Shook, 1990) to 0.47 (Windig et al., 2005).

The slightly negative estimate of the genetic correlation was not significantly different from zero between MEM and AFC ( -0.01 ; Table 3$)$. This estimate is closer to zero than those previously reported in studies of Holstein cattle, which have ranged from -0.44 to -0.20 (Moore et al., 1991; Cienfuegos-Rivas et al., 2006; Ruiz-Sánchez et al., 2007). Estimates of genetic correlations of MEF and MEP with AFC (-0.03 and 0.14 , respectively; Table 3) were also not significantly different from zero. The estimate of the genetic correlation between SCS and AFC (-0.06) was not different from zero (Table 3).

Estimates of genetic correlations of CAI with MEM, $\mathrm{MEF}$, and MEP were not significantly different from zero, with values ranging from -0.45 to 0.36 (Tables 3 , 4 , and 5). Most other studies have reported estimates of the genetic correlation between CAI (or days open) and milk yield ranging from 0.10 to 0.67 (Haile-Mariam et al., 2003; Kadarmideen et al., 2003; VanRaden et al., 2004). However, these small estimates of genetic correlations between production traits and CAI agree with some previous studies of the association between milk production traits and fertility, where unfavorable genetic relationships were not found (Dong and van Vleck, 1989; Pryce et al., 2002). Differences between the results of the present study and those reporting unfavorable genetic relationships between milk yield and fertility may be a result of peculiarities of the recorded Mexican Holstein population, with high environmental levels for milk production (Montaldo et al., 2009). 
Previous estimates for the genetic correlation between milk production and CAI for Mexican Holsteins were positive (Cienfuegos-Rivas et al., 2006). The heritability for CAI was also low, with an estimate of $81 \mathrm{~d}^{2}$ for its additive genetic variance compared with $90 \mathrm{~d}^{2}$ in the present study for first-parity data.

Estimates of genetic correlations between SCS and CAI were all negative, with more negative estimates for second- and third-parity data, but were not significantly different from zero (Tables 3, 4, and 5). VanRaden et al. (2004) reported a positive genetic correlation (0.30) between SCS and days open in US Holsteins.

\section{Environmental and Phenotypic Correlations}

There were high positive estimates of environmental correlations among MEM, MEF, and MEP, ranging from 0.82 to 0.96 (Tables 3,4 , and 5). There were moderate negative environmental correlation estimates $(-0.25$ to -0.15) among MEM, MEF, MEP, and SCS. Environmental correlation estimates between MEM, MEF, and MEP and CAI were positive and small (0.08-0.17; Tables 3, 4, and 5). Estimates of the environmental correlations between MEM, MEF, MEP, and AFC were small and negative $(-0.02$ to -0.04 ; Table 3$)$. The environmental correlation estimate between AFC and SCS was 0.07 (Table 3 ). The estimate of the environmental correlation between SCS and CAI varied from 0.02 and 0.07 , but was significant only for second- and thirdparity data (Tables 3, 4, and 5). Therefore, estimates of the environmental correlations were favorable among production traits, slightly favorable between production traits and SCS and between AFC and SCS, and unfavorable but small between MEM, MEF, and MEP and CAI. The environmental correlation estimate between SCS and CAI was slightly favorable. In all cases, the estimates of the phenotypic correlations were similar to those observed for the environmental correlations (Tables 3, 4, and 5).

\section{CONCLUSIONS}

Estimates of heritability and genetic variation for production traits and AFC were moderate, indicating that response to selection would be expected in this population. Estimates of heritability and genetic variation for SCS, and particularly for CAI, were smaller so that response to selection would be more difficult to obtain than for yield traits. Estimates of genetic correlations were large and favorable between production traits. Unfavorable genetic correlations were not found in this study between CAI or SCS with production traits, or between AFC and CAI. Estimates of environmental correlations were large and favorable between production traits, but other estimates were small. These parameter estimates can be used to design better breeding programs for the Mexican Holstein population involving an economic index of production traits, CAI, and SCS for ranking of sires. Relative economic values of each trait for local markets are needed for simultaneous selection of these traits and others of economic importance.

\section{ACKNOWLEDGMENTS}

The authors are thankful to Marcia Castillo-Mendoza (Universidad CESSA, Mexico City, Mexico) for proofreading the manuscript and to L. Dale Van Vleck (University of Nebraska-Lincoln) for many useful suggestions for improving the manuscript.

\section{REFERENCES}

Abdallah, J. M., and B. T. McDaniel. 2000. Genetic parameters and trends of milk, fat, days open, and body weight after calving in North Carolina experimental herds. J. Dairy Sci. 83:1364-1370.

Åkesson, M., S. Bensch, D. Hasselquist, M. Tarka, and B. Hansson. 2008 Estimating heritabilities and genetic correlations: Comparing the 'animal model' with parent-offspring regression using data from a natural population. http://www.plosone.org/article/ info\%3Adoi\%2F10.1371\%2Fjournal.pone.0001739 Accessed July $23,2009$.

Andersen-Ranberg, I. M., G. Klemetsdal, B. Heringstad, and T. Steine. 2005. Heritabilities, genetic correlations, and genetic change for female fertility and protein yield in Norwegian dairy cattle. J. Dairy Sci. 88:348-355.

Banos, G., and G. E. Shook. 1990. Genotype by environment interaction and genetic correlations among calvings for somatic cell count and milk yield. J. Dairy Sci. 73:2563-2573.

Carlén, E., E. Strandberg, and A. Roth. 2004. Genetic parameters for clinical mastitis, somatic cell score, and production in the first three lactations of Swedish Holstein cows. J. Dairy Sci. 87:30623070 .

Castillo-Juarez, H., P. A. Oltenacu, R. W. Blake, C. E. McCulloch, and E. G. Cienfuegos-Rivas. 2000. Effect of herd environment on the genetic and phenotypic relationships among milk yield, conception rate, and somatic cell score in Holstein cattle. J. Dairy Sci. 83:807-814.

Castillo-Juarez, H., P. A. Oltenacu, and E. G. Cienfuegos-Rivas. 2002. Genetic and phenotypic relationships among milk production and composition traits in primiparous Holstein cows in two different herd environments. Livest. Prod. Sci. 78:223-231.

Cerón-Muñoz, M. F., H. Tonhati, C. N. Costa, J. Maldonado-Estrada, and D. Rojas-Sarmiento. 2004. Genotype x environment interaction for age at first calving in Brazilian and Colombian Holsteins. J. Dairy Sci. 87:2455-2458.

Cienfuegos-Rivas, E. G., P. A. Oltenacu, R. W. Blake, and H. CastilloJuarez. 2006. Fertility responses of Mexican Holstein cows to US sire selection. J. Dairy Sci. 89:2755-2760.

Cienfuegos-Rivas, E. G., P. A. Oltenacu, R. W. Blake, S. J. Schwager, and H. Castillo-Juarez. 1999. Interactions of milk yield between Holstein in the US and México. J. Dairy Sci. 82:2218-2223.

de Haas, Y., W. Ouweltjes, J. ten Napel, J. J. Windig, and G. de Jong. 2008. Alternative somatic cell count traits as mastitis indicators for genetic selection. J. Dairy Sci. 91:2501-2511.

Dechow, C. D., G. W. Rogers, J. B. Cooper, M. I. Phelps, and A. L. Mosholder. 2007. Milk, fat, protein, somatic cell score, and days open among Holstein, Brown Swiss, and their crosses. J. Dairy Sci. 90:3542-3549. 
Dekkers, J. C. M., and J. P. Gibson. 1998. Applying breeding objectives to dairy cattle improvement. J. Dairy Sci. 81:19-35.

Dong, M. C., and L. D. van Vleck. 1989. Correlations among first and second lactation milk yield and calving interval. J. Dairy Sci. 72:1933-1936.

FAO- SAGARPA. 2002. Informe sobre la situación de los recursos genéticos pecuarios de México. http://www.infoaserca.gob.mx/ claridades/revistas/111/ca111.pdf Accessed April 3, 2009.

Gilmour, A. R., B. J. Gogel, B. R. Cullis, S. J. Welham, and R. Thompson. 2002. ASReml User Guide. Release 1.0. VSN International Ltd, Hemel Hempstead, UK.

González-Recio, O., and R. Alenda. 2005. Genetic parameters for female fertility traits and a fertility index in Spanish dairy cattle. J. Dairy Sci. 88:3282-3289.

Haile-Mariam, M., P. J. Bowman, and M. E. Goddard. 2003. Genetic and environmental relationship among calving interval, survival, persistency of milk yield and somatic cell count in dairy cattle. Livest. Prod. Sci. 80:189-200.

Haile-Mariam, M., M. J. Carrick, and M. E. Goddard. 2008. Genotype by environment interaction for fertility, survival, and milk production traits in Australian dairy cattle. J. Dairy Sci. 91:4840-4853.

Hansen, M., M. S. Lund, M. K. Sørensen, and L. G. Christensen. 2002. Genetic parameters of dairy character, protein yield, clinical mastitis, and other diseases in the Danish Holstein cattle. J. Dairy Sci. 85:445-452.

Hare, E., H. D. Norman, and J. R. Wright. 2006. Trends in calving ages and calving intervals for dairy cattle breeds in the United States. J. Dairy Sci. 89:365-370.

Ikonen, T., S. Morri, A. M. Tyrisevä, O. Ruottinen, and M. Ojala. 2004. Genetic and phenotypic correlations between milk coagulation properties, milk production traits, somatic cell count, casein content, and pH of milk. J. Dairy Sci. 87:458-467.

Kadarmideen, H. N., R. Thompson, M. P. Coffey, and M. A. Kossaibati. 2003. Genetic parameters and evaluations from single- and multiple- trait analysis of dairy cow fertility and milk production. Livest. Prod. Sci. 81:183-195.

Mark, T. 2004. Applied genetic evaluations for production and functional traits in dairy cattle. J. Dairy Sci. 87:2641-2652.

Montaldo, H. H., S. G. Núñez-Soto, F. J. Ruiz-López, and H. CastilloJuárez. 2009. Selection response for milk production in conventional production systems in Mexico, using genetic evaluations of Holstein sires from Canada and the United States. J. Dairy Sci. 92:5270-5275.

Moore, R. K., P. P. Kennedy, L. R. Schaeffer, and J. E. Moxley. 1991. Relationships between age and body weight at calving and production in first lactation Ayrshires and Holsteins. J. Dairy Sci. 74:269-278.

Neuenschwander, T., H. N. Kadarmideen, S. Wegmann, and Y. De Haas. 2005. Genetics of calving-dependant production increase and its relationship with health, fertility, longevity, and conformation in Swiss Holsteins. J. Dairy Sci. 88:1540-1551.

Ojango, J. M. K., and G. E. Pollott. 2001. Genetics of milk yield and fertility traits in Holstein-Friesian cattle on large-scale Kenyan farms. J. Anim. Sci. 79:1742-1750.

Olori, V. E., T. H. E. Meuwissen, and R. F. Verkamp. 2002. Calving interval and survival breeding values as measure of cow fertility in a pasture-based production system with seasonal calving. J. Dairy Sci. 85:689-696.

Pirlo, G., F. Miglior, and M. Speroni. 2000. Effect of age at first calving on production traits and on difference between milk yield returns and rearing costs in Italian Holsteins. J. Dairy Sci. 83:603-608.

Pösö, J., and E. A. Mäntysaari. 1996. Genetic relationships between reproductive disorders, operational days open and milk yield. Livest. Prod. Sci. 46:41-48.
Powell, R. L., and G. R. Wiggans. 1991. Animal model evaluations for Mexican Holsteins. J. Dairy Sci. 74:1420-1427.

Pryce, J. E., M. P. Coffey, S. H. Brotherstone, and J. A. Woolliams. 2002. Genetic relationships between calving interval and body condition score conditional on milk yield. J. Dairy Sci. 85:15901595.

Raffrenato, E., R. W. Blake, P. A. Oltenacu, J. Carvalheira, and G. Licitra. 2003. Genotype by environment interaction for yield and somatic cell score with alternative environmental definitions. J. Dairy Sci. 86:2470-2479.

Ruiz-Sánchez, R., R. W. Blake, H. M. A. Castro Gámez, F. Sánchez, H. H. Montaldo, and H. Castillo-Juárez. 2007. Short communication: Changes in the association between milk yield and age at first calving in Holstein cows with herd environment level for milk vield. J. Dairy Sci. 90:4830-4834.

Shanks, R. D., P. J. Berger, A. E. Freeman, and F. N. Dickinson. 1982. Genetic and phenotypic relations of milk production and postpartum length with health and lactation curve traits by lactation. J. Dairy Sci. 65:1612-1623.

SIAP-SAGARPA. 2009. Servicio de información agroalimentaria y pesquera. http://www.siap.sagarpa.gob.mx/ Accessed April 3, 2009.

USDA-ARS. 2009. Trait means for base cows. http://aipl.arsusda.gov/ eval/summary/Bmean_bases_het.cfm/ Accessed May 20, 2009.

Valencia, P. M., H. H. Montaldo, and F. Ruiz. 2008. Parámetros genéticos para características de conformación, habilidad de permanencia a los 48 meses de edad y producción de leche en ganado Holstein en México. Técnica Pecuaria Méx. 46:235-248.

Valencia, P. M., F. Ruiz, and H. H. Montaldo. 2004a. Estimación de parámetros genéticos para características de longevidad y producción de leche en ganado Holstein en México. Interciencia 29:52-56.

Valencia, P. M., F. Ruiz, and H. H. Montaldo. 2004b. Genetic and environmental variance components for milk yield across regions, time periods and herd levels for Holstein cattle in México. Rev. Científica de Veterinaria. LUZ (Venezuela) 14:404-411.

Valencia, P. M., F. Ruiz, H. H. Montaldo, J. F. Keown, and L. D. Van Vleck. 1999. Evaluación genética para la producción de leche en ganado Holstein en México. Técnica Pecuaria Méx. 37:1-7.

Van Tassell, C. P., I. Misztal, and L. Varona. 2000. Method R estimates of additive genetic, dominance genetic, and permanent environmental fraction of variance for yield and health traits of Holsteins. J. Dairy Sci. 83:1873-1877.

VanRaden, P. M. 2004. Invited review: Selection on net merit to improve lifetime profit. J. Dairy Sci. 87:3125-3131.

VanRaden, P. M., A. H. Sanders, M. E. Tooker, R. H. Miller, H. D. Norman, M. T. Kuhn, and G. R. Wiggans. 2004. Development of a national genetic evaluation for cow fertility. J. Dairy Sci. $87: 2285-2292$.

Veerkamp, R. F., E. P. C. Koenen, and G. De Jong. 2001. Genetic correlations among body condition score, yield, and fertility in first-parity cows estimated by random regression models. J. Dairy Sci. 84:2327-2335.

Weller, J. I., and E. Ezra. 2004. Genetic analysis of the Israeli Holstein dairy cattle population for production and nonproduction traits with a multitrait animal model. J. Dairy Sci. 87:1519-1527.

Welper, R. D., and A. E. Freeman. 1992. Genetic parameters for yield traits of Holsteins, including lactose and somatic cell score. J. Dairy Sci. 75:1342-1348.

Wiggans, G. R., and L. D. Van Vleck. 1979. Extending partial lactation milk and fat records with a function of last-sample production. J. Dairy Sci. 62:316-325.

Windig, J. J., M. P. L. Calus, and R. F. Veerkamp. 2005. Influence of herd environment on health and fertility and their relationship with milk production. J. Dairy Sci. 88:335-347. 